\title{
Electrolyzed Oxidized Water (EOW): Non-Thermal Approach for Decontamination of Food Borne Microorganisms in Food Industry
}

\author{
Subrota Hati ${ }^{1 *}$, Surajit Mandal ${ }^{1}$, P. S. Minz ${ }^{2}$, Shilpa Vij ${ }^{1}$, Yogesh Khetra ${ }^{3}$, B. P. Singh ${ }^{1}$, \\ Dipika Yadav ${ }^{1}$ \\ ${ }^{1}$ Dairy Microbiology Division, National Dairy Research Institute, Deemed University, Karnal, India; ${ }^{2}$ Dairy Engineering Division, \\ National Dairy Research Institute, Deemed University, Karnal, India; ${ }^{3}$ Dairy Technology Division, National Dairy Research Institute, \\ Deemed University, Karnal, India. \\ Email: *subrota_dt@yahoo.com
}

Received December 13 $3^{\text {th }}, 2011$; revised April 11 ${ }^{\text {th }}, 2012$; accepted April $18^{\text {th }}, 2012$

\begin{abstract}
Electrolyzed Oxidized Water (EOW) is produced by passing a diluted salt solution through an electrolytic cell, having anode and cathode electrodes. The anode and cathode are separated by a bipolar membrane. Negatively charged ionschloride and hydroxide in the diluted salt solution move to anode to give up electrons and become gas $\left(\mathrm{O}_{2}, \mathrm{Cl}_{2}\right)$ and hypochlorous acid and having redox potential of +700 to $+800 \mathrm{mV}$ with $\mathrm{pH} 4.0$. It has a strong oxidation potential and a shortage of electrons giving it the ability to oxidize and sterilize. In microbial inactivation process, oxidized water damage cell membranes, create disruption in cell metabolic processes and essentially kill the cell. EOW, also a strong acid, is different to hydrochloric acid or sulfuric acid in that it is not corrosive to skin, mucous membrane, or organic material. It is easy to handle and suitable for the sanitation of the plant and decontamination of foods. Electrolyzed water has been tested and used as a disinfectant in the food industry and other applications.
\end{abstract}

Keywords: Electrolyzed; Oxidized; Anode; Disinfectant; Food; Microorganisms

\section{Introduction}

Since the mid 1980's, electrolyzed water has been certified for use in Japan as a medical product. The first form of electrolyzed water (EO) that was developed was the acidic type, and it was accepted quickly by the food industry in Japan. It was found to be useful at killing bacteria and parasites on raw fish without altering the sensory characteristics of the fish. Although Hazard Analysis Critical Control Point (HACCP) system has been implemented in many food processing establishments, most outbreaks of food-borne illnesses still occurred in foodservice sectors including institutions, fast food restaurants, and food stores, where food products had undergone various treatments and should have been rendered as safe [1]. This situation indicates that hazards might still exist in the food supply systems. Today, food chains are becoming complicated in handling, processing, transportation, and storage ensuring a safe food supply becomes a challenge task. Electrolyzed water definitely has a lot of potential uses for the food industry. Possibili-

"Corresponding author. ties for the use of electrolyzed water are growing but one basic and proven application is using it as a disinfectant on food contact surfaces. This is advantageous to Industry because it involves on-site production of the disinfectant, which means there are no chemicals to store or handling costs of chemicals to deal with [2]. The major advantages of using EOW for inactivation of bacteria are less adverse environmental impacts and without the difficulties of transporting and storing potentially hazardous chemicals [3]. Another proven effective use is its application directly on fresh food products to reduce the number of microorganisms or pathogens present. It may even have the prospect of replacing the use of pesticides [2]. It also has possibilities in the area of specialized food products. There is potential use of electrolyzed water on food products that can be of benefit to people with diseases such as gout. It could be used to decrease the amount of purine in foods such as red meats and scallops, so people who suffer from gout are better able to consume the product and not suffer from the effects of that disease [4]. EO water is generated through the electrolysis of a dilute solution of $\mathrm{NaCl}$ and softened tap water 
passed through on electrolysis chamber. EO water is produced by passing a salt solution (12\%) across a bipolar membrane, resulting in two solutions: an acidic solution that is characterized by a low $\mathrm{pH}$, high oxidation-reduction potential (ORP), and a free chlorine concentration of approximately $50 \mathrm{ppm}$; the basic solution is composed of a high $\mathrm{pH}$ and low ORP [5]. The sodium ions are drawn to the cathode $(\mathrm{NaOH})$ and the chlorine ions are drawn to the anode $(\mathrm{HOCl})$. The alkaline $\mathrm{EO}$ water so collected has a $\mathrm{pH}$ of approximately 11.4 and ORP of $795 \mathrm{mV}$, while acidic EO water has a $\mathrm{pH}$ of approximately 2.6 , ORP of $1150 \mathrm{mV}$ and a chlorine concentration 40 and $90 \mathrm{ppm}$. EO water has been utilized to disinfect kitchen cutting boards, and other surfaces, fresh cut vegetables, alfalfa seeds and sprouts, broccoli, strawberry, lettuce, tomatoes, apple and poultry $[6,7]$. Electrolyzed oxidizing water (EOW) has been reported to have strong bactericidal effects on many pathogenic bacteria, such as Escherichia coli O157:H7 [8], Listeria monocytogenes [9], Bacillus cereus [10], and Salmonella sp. [11]. In addition, it could disinfect hepatitis B virus and human immunodeficiency virus [12] and reduce germinations of many fungal species [10]. EOW can also be used in agriculture for sterilization of fruits and vegetables [13], food materials and food processing materials $[14,15]$ studied using acidic EO water to treat fresh-cut vegetables, and achieved up to a $2.6 \log 10 \mathrm{CFU} / \mathrm{g}$ reduction in bacterial population. In another study, EO water was used to disinfect plastic kitchen cutting board, which reduced E. coli O157:H7 populations more than $5.0 \mathrm{log}$ $\mathrm{CFU} / 100 \mathrm{~cm}^{2}$ [16]. Using acidic EO water against pure cultures of Enterobacter aerogenes and Staphylococcus aureus yielded $9 \log 10 \mathrm{CFU} / \mathrm{g}$ reduction after $30 \mathrm{~s}$ treatment [16]. EO water also has the potential to be more cost effective than traditional disinfectants. Electrolyzed oxidizing (EO) water is a relatively new disinfecting compound that has shown promise against cells suspendsions of Escherichia coli (EC) O157:H7, Salmonella enteritidis, and Listeria monocytogenes [16], E. coli O157:H7 and L. monocytogenes attached to cutting boards [17], spoilage organisms associated with vegetables, pathogens in solution, or pathogens attached to poultry surfaces. It is less dangerous and less expensive than most traditional preservation methods.

\section{Basic Principle and EO Water Generation Process}

EO water was initially developed in Japan [18]. It has been reported to have strong bactericidal effects on most pathogenic bacteria that are important to food safety. EO water is produced by passing a diluted salt solution through an electrolytic cell, within which the anode and cathode are separated by a membrane. Generation of EO water involved electrolysis of sodium chloride in a cell containing inert positively charged and negatively charged platinum electrodes separated by a bipolar membrane. A salt solution $(12 \% \mathrm{NaCl})$ and deionized water were pumped into the EO water generator (ROX Water Electrolyzer, Hoshizaki America, Inc., Peachtree City, GA). By subjecting the electrodes to direct current voltage, two types of water possessing different characteristics were produced: an electrolyzed basic aqueous solution (EOB; $\mathrm{pH}$ of 11.6 and oxidation-reduction potential [ORP] of $795 \mathrm{mV}$ ) and an electrolyzed acidic solution (EOA; pH range of $2.3-2.7,1150 \mathrm{mV}$ ORP, and approximately $50 \mathrm{ppm}$ free chlorine). Amperage for generation of EO water can be adjusted manually with this system. Two types of water are produced simultaneously. EO water, with low $\mathrm{pH}(2.3$ - 2.7), high oxidation-reduction potential $(\mathrm{ORP},>1000 \mathrm{mV}$ ), high dissolved oxygen and contains free chlorine (concentration depends on the EO water machine setting), is produced from anode side. However, electrolyzed reduced (ER) water, with high $\mathrm{pH}(10.0$ - 11.5), high dissolved hydrogen, and low ORP ( 800 to $900 \mathrm{mV}$ ), is produced from the cathode side. ER water with strong reducing potential can be used to remove dirt and grease from items such as cutting boards and other kitchen utensils [19].

The principle of producing electrolyzed water is shown in the following (Figure 1):

\section{Positivepole:}

$\begin{array}{lll}2 \mathrm{H}_{2} \mathrm{O} & \rightarrow & 4 \mathrm{H}^{+}+\mathrm{O}_{2}+4 \mathrm{e}^{-} \\ 2 \mathrm{NaCl} & \rightarrow & \mathrm{Cl}_{2}+2 \mathrm{e}^{-}+2 \mathrm{Na}^{+} \\ \mathrm{Cl}_{2}+\mathrm{H}_{2} \mathrm{O} & \rightarrow & \mathrm{HCl}+\mathrm{HOCl}\end{array}$

\section{Negativepole:}

$\begin{array}{ccc}2 \mathrm{H}_{2} \mathrm{O}+2 \mathrm{e}^{-} & \rightarrow & 2 \mathrm{OH}^{-}+\mathrm{H}_{2} \\ & & \uparrow \\ 2 \mathrm{NaCl}+2 \mathrm{OH}^{-} & \rightarrow & 2 \mathrm{NaOH}+\mathrm{Cl}^{-}\end{array}$

\subsection{Substances Generated at Anode}

1) Hypochlorous acid ( $\mathrm{HClO})$

2) Chlorine gas $\left(\mathrm{Cl}_{2}\right)$

Chlorine changes its existence form depending on the $\mathrm{pH}$ of the solution. As the $\mathrm{pH}$ of electrolyzed acidic water is around 2.5, it consists of $85 \%$ of hypochlorous acid and $15 \%$ of chlorine gas. Therefore, the available chlorine in electrolyzed acidic water refers to a combination of hypochlorous acid and chlorine gas. The amount of chlorine gas production is as little as $0.012 \mathrm{ml} / \mathrm{min}(15 \mathrm{~A}$, $2.5 \mathrm{~L} / \mathrm{min})$. In contrast, sodium hypochlorite (ClO-, hypochlorite ion) widely used in the market has a $\mathrm{pH}$ of 


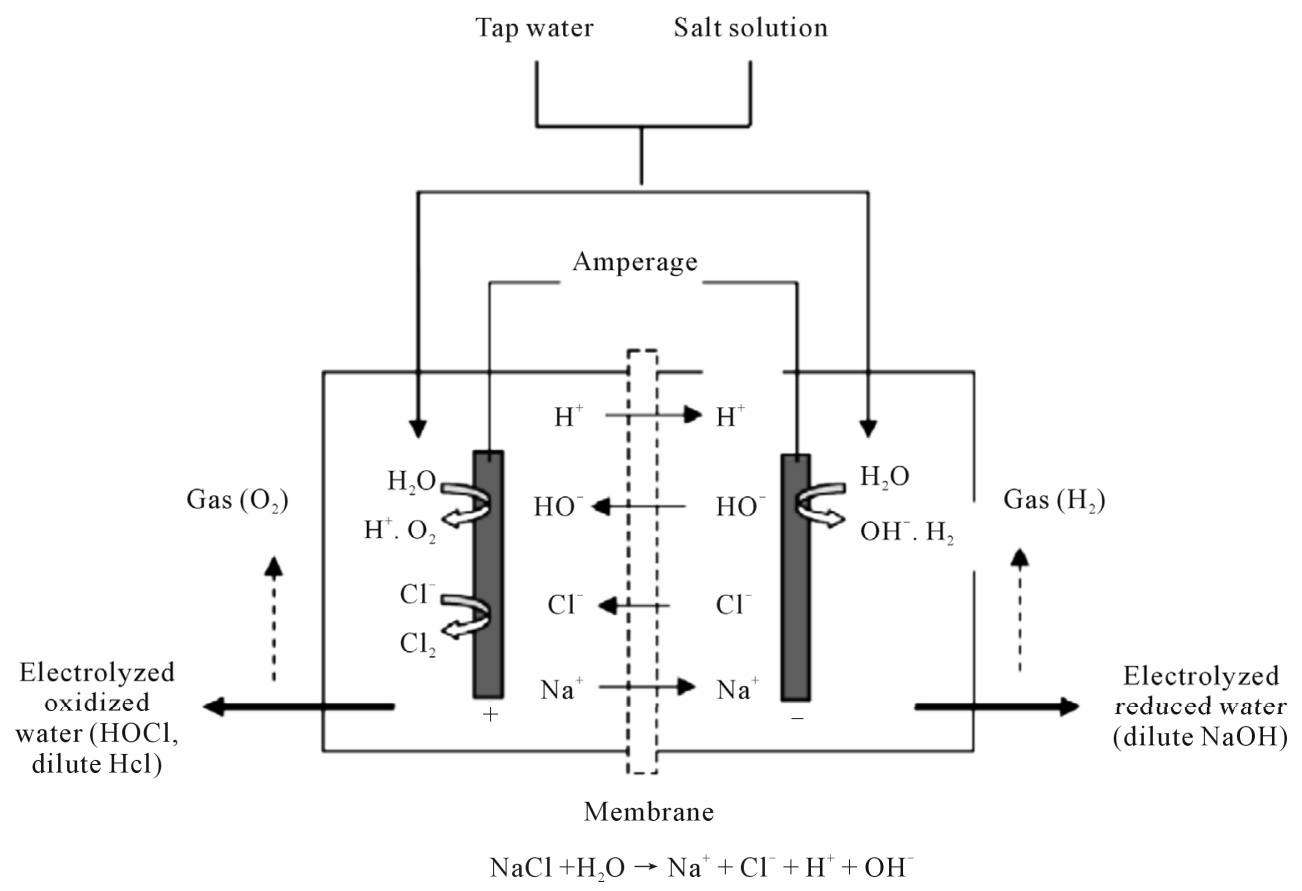

Figure 1. Schematic diagram of EO water generation system.

around 10 .

3) Hydrochloric acid $(\mathrm{HCl})$

The $\mathrm{pH} 2.5$ of electrolyzed acidic water is due to the generation of extremely dilute hydrochloric acid. The Poisonous Material Control Law specifies a minimum of $10 \%$. But the concentration of hydrochloric acid in acidic water is around $0.01 \%$, which is about $1 / 1000$ of the specified level.

4) Oxygen gas $\left(\mathrm{O}_{2}\right)$

More than $99.9 \%$ of generated gas is oxygen. Its generation rate is about $24 \mathrm{ml} / \mathrm{min}(15 \mathrm{~A}, 2.5 \mathrm{~L} / \mathrm{min})$.

\subsection{Substances Generated in Alkaline Water}

1) Sodium hydroxide

The $\mathrm{pH} 11.5$ of electrolyzed alkaline water is due to the generation of extremely dilute sodium hydroxide. The Poisonous Material Control Law specifies a minimum of $5 \%$. But the concentration of sodium hydroxide in acidic water is around $0.013 \%$, which is about $1 / 400$ of the specified level.

2) Hydrogen gas

Almost $100 \%$ of generated gas is hydrogen. Its generation rate is about $112 \mathrm{ml} / \mathrm{min}(15 \mathrm{~A}, 2.5 \mathrm{~L} / \mathrm{min})$. The explosive limit (maximum volume concentration) in the air is $4 \%-75 \%$. But generated gas is exhausted outdoors and causes no problem. For example, in a totally enclosed $5 \times 5 \times 3 \mathrm{~m}\left(75 \mathrm{~m}^{3}\right)$ room, hydrogen gas concentration will not reach the explosive limit of $4 \%$ unless the unit is continuously operated for more than 440 hours.
The main advantage of EO water is its safety. EO water which is also a strong acid is different to hydrochloric acid or sulfuric acid in that it is not corrosive to skin, mucous membrane, or organic material. On the other hand, sodium hypochlorite was proved to have a strong toxicity, such as skin irritation, membrane irritation, acute toxicity, and so on [20]. Currently used hatchery sanitizers (formaldehyde gas and glutaraldehyde) are noxious to humans and chicks, and may pose a serious health risk [21]. Furthermore, the use of formaldehyde gas and glutaraldehyde are gradually being limited because of the adverse effects this chemical has on the environment [22] also stated that EO water provides a useful means of cleaning and disinfecting digestive endoscopes between patients. It is safe for the human body and for the environment. In addition, the cost of using EO water is much less expensive (5.3 yen/L) compared with glutaraldehyde (1200 yen/L) [22]. When EO water comes into contact with organic matter, or is diluted by tap water or reverse osmosis (RO) water, it becomes ordinary water again. Thus, it's less adverse impact on the environment as well as users' health. Moreover, compared with other conventional disinfecting techniques, EO water reduces cleaning times, is easy to handle, has very few side effects, and is relative cheap [23]. Chemicals used for cleaning and disinfection are expensive and represent an operating expense for the dairy producer. Once the initial capital investment is made to purchase an EO water generator, the only operating expenses are water, salts and electricity to run the unit [24] The main 
disadvantage of EO water is that the solution rapidly loses its antimicrobial activity if $\mathrm{EO}$ water is not continuously supplied with $\mathrm{H}^{+}, \mathrm{HOCl}$ and $\mathrm{Cl}_{2}$ by electrolysis [25]. EO water is gaining a reputation in various fields as a more capable disinfectant than conventional chemical disinfectants. However, problems, such as chlorine gas emission, metal corrosion, and synthetic resin degradation, due to its strong acidity and free chlorine content have been a matter of concern. Although metal corrosion and synthetic resin degradation occurred, they were not serious on hemodialysis equipment $[23,26]$ also indicated that EO water did not have any adverse effect on stainless steel, it can still be safely used as a sanitizer to inactivate bacteria on food contact surfaces made from stainless steel in food processing. After disinfection, washing food equipment with sterile water can completely avoid metal corrosion. During the EO water generation process, chlorine ions are generated, and thus chlorine gas is emitted. This necessitates the use of standard-type extractor fan.

\section{Inactivation of Microbes Using EO Water}

EO water may inactivate both vegetative cells and bacterial endospores. Three basic mechanisms have been attributed to the inactivation of microbial spores during EO water treatment. These include destruction of DNA by UV irradiation, volatilization of compounds from the spore surface by UV-photons and erosion or so called "etching" of the spore surface by adsorption of reactive species like free radicals. Many studies have been conducted in evaluating the bactericidal activity of $\mathrm{EO}$ water. EO water possess antimicrobial activity on a variety of microorganisms including Pseudomonas aeruginosa [25, 27] Staphylococcus aureus [27], S. epidermidis, E. coli O157:H7 [17,28,29], Salmonella enteritidis [17], Salmonella Typhimurium [11], Bacillus cereus [27,30,31], Listeria monocytogenes [11,27,29], Campylobacter jejuni [18], Enterobacter aerogenes [32] and Vibrio parahaemolyticus [33]. EO water can also reduce germination of many fungal species, such as Alternaria spp., Bortrytis spp., Cladosporium spp., Colletotrichum spp., Curvularia lunata, Didymella bryonaie, Epicoccum nigrum, Fusarium spp., Helminthosporium spp., Pestalotia spp., Phomopsis longicolla, Rhodosporidium toruloides, Stagonospora nodorum, Thielaviopsis basicola, Trichoderma spirale, Acidovorax avenae subsp., Erwinia chrysanthemi, Pantoea ananatis, Pseudomonas syringae [10], Aspergillus spp. [10], Botryosphaeria berengeriana (AlHaq et al., 2002), Monilinia fructicola (Al-Haq et al., 2001; 10], Penicillium expansum and Tilletia indica. In general, bacteria generally grow in a $\mathrm{pH}$ range of $4-9$. Aerobic bacteria grow mostly at ORP range +200 to 800
$\mathrm{mV}$, while anaerobic bacteria grow well at +700 to +200 $\mathrm{mV}$. High ORP in the EO water cause the modification of metabolic fluxes and ATP production, probably due to the change in the electron flow in cells. Low $\mathrm{pH}$ may sensitize the outer membrane of bacterial cells to the entry of $\mathrm{HOCl}$ into bacterial cells. $\mathrm{HOCl}$, the most active of the chlorine compounds, appears to kill the microbial cell through inhibiting glucose oxidation by chlorine-oxidizing sulfhydryl groups of certain enzymes important in carbohydrate metabolism. Other modes of chlorine action that have been proposed are: 1) disruption of protein synthesis; 2) oxidative decarboxylation of amino acids to nitrites and aldehydes; 3) reactions with nucleic acids, purines, and pyrimidines; 4) unbalanced metabolism after the destruction of key enzymes; 5) induction of deoxyribonucleic acid (DNA) lesions with using a scanning electron microscope. The cells treated with electrolyzed acidic water had wrinkled cell wall with round pores in which the cytoplasmic structures were flushed out (Figure 2). [28] has developed chemically modified water from deionized water with the same properties (i.e., $\mathrm{pH}$, chlorine and ORP) as EO water without using electrolysis. Their results suggested that ORP of EO water might be the primary factor responsible for the bactericidal effect. However, ORP is not the main factor of antimicrobial activity because the higher ORP of ozonated water did not show higher disinfectant effect than lower ORP of EO water. They further defined that free chlorine of EO water, mainly hypochlorous acid ( $\mathrm{HOCl})$, produces hydroxyl radical $\left(\mathrm{OH}^{-}\right)$that acts on microorganisms. Ozone solution produces $\mathrm{OH}$, too. The higher $\mathrm{OH}$ produced by higher $\mathrm{HOCl}$ concentration in $\mathrm{EO}$ water means the better the disinfectant efficacy than ozone solution. The relative concentrations of aqueous molecular chlorine, $\mathrm{HOCl}$, hypochlorite ion $(\mathrm{OCl})$ and chlorine gas $\left(\mathrm{Cl}_{2}\right)$ were also the factors that accounted for the bactericidal potency. At $\mathrm{pH} 4$, EO water with the maximum concentration of $\mathrm{HOCl}$ had the maximum microbiocidal activity. [29] investigated the effects of chlorine and $\mathrm{pH}$ on efficacy of EO water for inactivating E. coli O157:H7 and $L$. monocytogenes. EO water is very effective for inactivating E. coli O157:H7 and L. monocytogenes in a wide $\mathrm{pH}$ range (between 2.6 and 7.0), if sufficient free chlorine $(>2 \mathrm{mg} / \mathrm{L})$ is present. For each chlorine content, bactericidal activity and ORP increased with decreasing $\mathrm{pH}$. Based on fluorescent and spectroscopic measurements, [34] reported that the ORP of EO water could damage the outer and inner membranes of E. coli O157:H7. The redox state of the glutathione disulfide-glutathione couple (GSSG/2GSH) can serve as an important indicator of redox environment. There are many redox couples in a cell that work together to maintain the redox environment. The inactivation mechanism hypothesized was that 


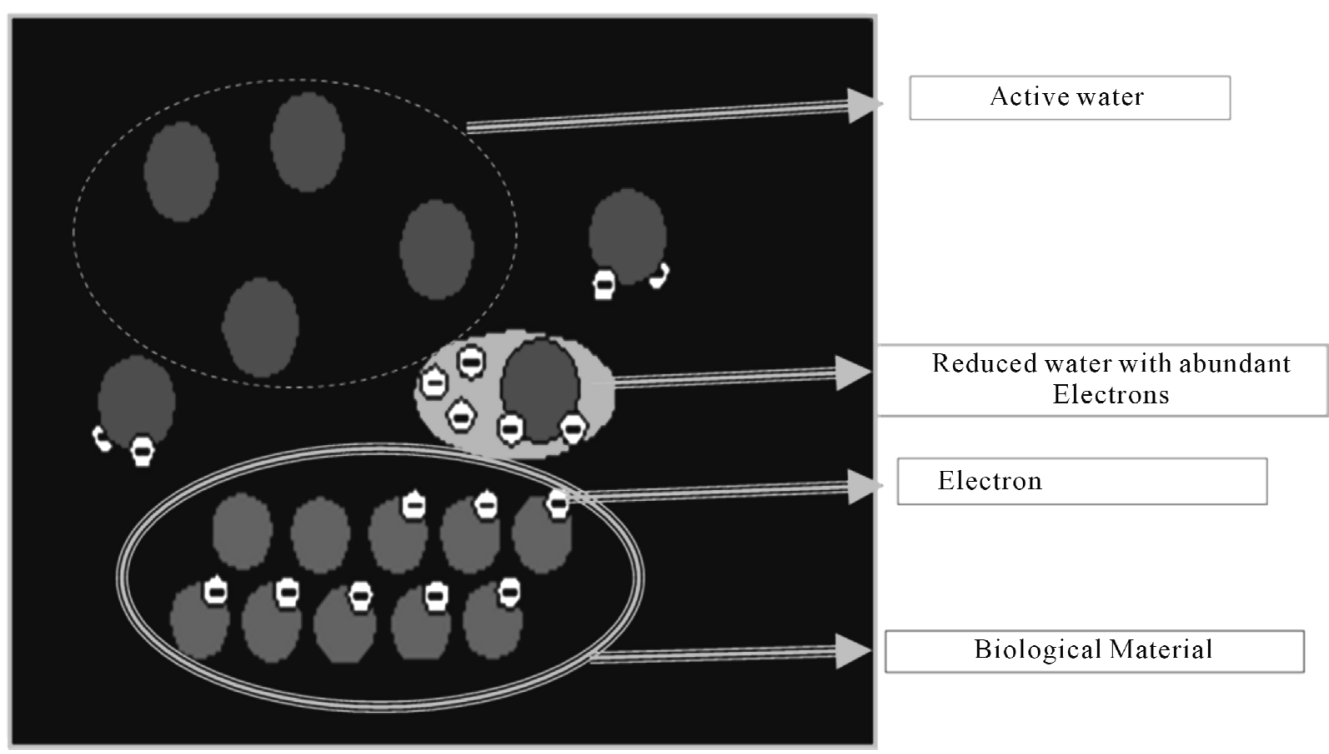

Figure 2. An oxidizing agent snatching away electrons from bacteria and kill them.

ORP could damage the redox state of GSSG/2GSH and then penetrate the outer and inner membranes of cell, giving rise to the release of intracellular components and finally cause the necrosis of E. coli O157:H7. Thus, the antimicrobial effect of EO water derives from the combined action of the hydrogen ion concentration, oxidation-reduction potential and free chlorine. Storage conditions can affect chemical and physical properties of EO water. When stored under an open, agitated and diffused light condition the EO water had the highest chlorine loss rate. Under open condition, chlorine loss through evaporation followed first-order kinetics. The rate of chlorine loss was increased around 5-fold with agitation, but it was not significantly affected by diffused light [35]. EO water exposed to the atmosphere could reduce more chlorine and oxygen than that kept to a closed systems for a longer time $[11,36]$ reported that $\mathrm{EO}$ water stored at $4^{\circ} \mathrm{C}$ was more stable than stored at $25^{\circ} \mathrm{C}$. The effectiveness of chlorine as a bactericidal agent is reduced in the presence of organic matter due to the formation of combined available chlorines. At an identical chlorine concentration, the combined available chlorines had much lower bactericidal activity than the free form [37]. The accompanying loss of DNA-transforming ability; 6) inhibition of oxygen uptake and oxidative phosphorylation, coupled with leakage of some macromolecules; 7) formation of toxic N-chlorine derivatives of cytosine; and 8) creation of chromosomal aberrations [38]. A theory for inactivation of bacteria based on the high oxidation potential of EO water causing damage of cell membranes was reported by [34]. The chemical process of oxidation occurs when oxygen contacts with other compounds causing them to lose electrons and further causing the compounds to break down and change functions. In the case of microbes, oxidation could damage cell membranes, create disruption in cell metabolic processes and essentially kill the cell.

\section{Potential Application of EOW in Food Processing}

Application of electrolyzed oxidizing water to reduce Listeria monocytogenes on ready-to-eat meats [11]. Experiments were conducted to determine the effectiveness of acidic (EOA) or basic electrolyzed oxidizing (EOB) water, alone or in combination, on ready-to-eat (RTE) meats to reduce Listeria monocytogenes. The Centers for Disease Control and Prevention (CDC) considers E. coli O157:H7 and L. monocytogenes to be of great concern because of the severity and number of illnesses they cause [39]. Frankfurters or ham surfaces were experimentally inoculated with $L$. monocytogenes and subjected to dipping or spraying treatments $\left(25^{\circ} \mathrm{C}\right.$ or $4^{\circ} \mathrm{C}$ for up to $30 \mathrm{~min}$ ) with $\mathrm{EOA}, \mathrm{EOB}$, and other food grade compounds. L. monocytogenes was reduced the greatest when frankfurters were treated with EOA and dipped at $25^{\circ} \mathrm{C}$ for $15 \mathrm{~min}$. Reductions greater than $1 \mathrm{log} \mathrm{CFU} / \mathrm{g}$ were not observed for the duration of the study. Even with a prolonged contact time, treatments with EOA or EOB were not enough to meet regulatory requirements for control of LM on RTE meats. Additional studies required to identify food grade antimicrobials to control the pathogen on RTE meats are warranted.

EO water has been used as a disinfectant for food processing equipment. EO water ( $\mathrm{pH}$ of 2.53 , ORP of $1178 \mathrm{mV}$ and chlorine of $53 \mathrm{mg} / \mathrm{L}$ ) could also reduce 
Enterobacter aerogenes and S. aureus on glass, stainless steel, glazed ceramic tile, unglazed ceramic tile and vitreous china surfaces. Immersion of these surfaces in EO water for $5 \mathrm{~min}$ with agitation $(50 \mathrm{rpm})$ reduced populations of E. aerogenes and S. aureus on the tested surfaces to $<1 \mathrm{CFU} / \mathrm{cm}^{2}$ [32]. Listeria monocytogenes is a foodborne pathogen that can lead to potentially life-threatening listeriosis in high-risk populations. [8] investigated the resistance of $L$. monocytogenes biofilms on stainless steel surfaces to EO water ( $\mathrm{pH}$ of 2.60, ORP of $1160 \mathrm{mV}$ and chlorine of $56 \mathrm{mg} / \mathrm{L}$ ) and found that a $300 \mathrm{~s}$ treatment on a stainless steel surface, could reduce the $L$. monocytogenes from $1.9 \times 10^{10} \mathrm{CFU} / 82.5 \mathrm{~cm}^{2}$ to below detection levels. However, it took $300 \mathrm{~s}$ of exposure to $200 \mathrm{mg} / \mathrm{L}$ chlorine solution to achieve the same result.

Fresh-cut apples (approx. $600 \mathrm{~g}$ ) were disinfected by sodium hypochlorite ( $\mathrm{pH} 9.3$, available chlorine $200 \mathrm{mg} /$

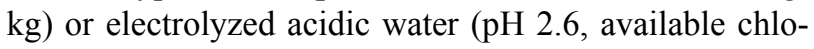
rine $30 \mathrm{mg} / \mathrm{kg}$ ), rinsed thoroughly with tap water for 15 seconds and checked with chlorine test paper for residual chlorine [40]. EO water containing $50 \mathrm{mg} / \mathrm{L}$ chlorine had a stronger bactericidal effect than that containing 15 or $30 \mathrm{mg} / \mathrm{L}$ chlorine. The treatment did not cause discoloration of fresh-cut produces. Rinsing EO water $(50 \mathrm{mg} / \mathrm{L})$ treated fresh-cut produces with fresh water did not increase the bacterial reduction due to the additive effects of the sequential treatment. [41] reported that cucumbers washed with ER water (pH of 11.3, ORP of $-870 \mathrm{mV}$ ) for $5 \mathrm{~min}$ and then soaked in EO water ( $\mathrm{pH}$ of 2.6, ORP of $1130 \mathrm{mV}$ and free chlorine of $30 \mathrm{mg} / \mathrm{L}$ ) for $5 \mathrm{~min}$ showed a reduction in aerobic mesophiles. Lettuce with smooth surfaces have been used for the investigation of the effectiveness of EO water on bacterial reduction. [42] observed that shaking lettuce with EO water $(45 \mathrm{mg} / \mathrm{L}$ free chlorine) at $100 \mathrm{rpm}$ for $3 \mathrm{~min}$ significantly decreased mean populations of E. coli $\mathrm{O} 157: \mathrm{H} 7$ and $L$. monocytogenes by 2.41 and $2.65 \log \mathrm{CFU}$ per lettuce leaf, respectively, when compared with sterile $\mathrm{H}_{2} \mathrm{O}_{2}$ treatment. The result was in agreement with that of [15] who pointed out that EO water $(50 \mathrm{mg} / \mathrm{L}$ of free chlorine) treatment of shredded lettuce did not significantly affect the quality characteristics such as color and general appearance.

Electrolyzed alkaline water contains a small amount of sodium hydroxide which is a material of soap, and is effective in washing away proteins, fats and oils which are hard to wash by water. [33] also reported that EO water was a very effective sanitizer used for cleaning fish contacting surfaces in traditional grocery stores and fish markets, so that secondary bacterial contamination could be prevented. EO water was especially effective in reducing the population of E. coli and V. parahaemolyticus contamination on tilapia.
[43] found that treating raw salmon with EO water $(\mathrm{pH}$ of 2.6, ORP of $1150 \mathrm{mV}$ and free chlorine of $90 \mathrm{mg} / \mathrm{L}$ ) at $35^{\circ} \mathrm{C}$ for $64 \mathrm{~min}$ resulted in a $1.07 \log \mathrm{CFU} / \mathrm{g}(91.1 \%)$ and $1.12 \log \mathrm{CFU} / \mathrm{g}(92.3 \%)$ reduction in E. coli O157:H7 and L. monocytogenes, respectively. [44] stated that gloves used in handling food for protection of the worker and seller could become a carrier of pathogens through the contact of raw materials or contaminated surfaces. However, applications of EO water following a thorough cleaning greatly reduced $L$. monocytogenes population on gloves and seafood processing plants. Soaking inoculated gloves in EO water ( $\mathrm{pH}$ of 2.6, ORP of $1125 \mathrm{mV}$ and free chlorine of $40 \mathrm{mg} / \mathrm{L}$ ) at room temperature for $5 \mathrm{~min}$ completely eliminated $L$. monocytogenes on gloves (> $\left.4.46 \log \mathrm{CFU} / \mathrm{cm}^{2}\right)$ [44]. The treatment by immersion in EO water containing $50 \mathrm{mg} / \mathrm{L}$ chlorine for $5 \mathrm{~min}$ significantly reduced $L$. monocytogenes on tested surfaces (3.73 $\log / 25 \mathrm{~cm}^{2}$ on stainless steel sheet, $4.24 \log / 25 \mathrm{~cm}^{2}$ on ceramic tile and $1.52 \mathrm{log} / 25 \mathrm{~cm}^{2}$ on floor tile) [45].

\section{Safety Concern of EOW}

Use of EO water in different ways such as cleaning, sanitation on the surfaces of food processing equipments, decontamination or inactivation of food borne microorganisms present in fruits, vegetables or meat, sea foods etc. raise an issue of food safety. Different testings for EO water related to food safety has been followed [46].

\subsection{Cytotoxicity Test}

The number of colonies showed no significant difference between incubation with electrolyzed acidic water and incubation with distilled water for injection as a negative control.

\subsection{Reverse Mutation Test (Ames Test)}

No reverse mutation occurred in any bacterial species cultured with electrolyzed acidic water, showing its nonmutagenicity.

\subsection{Chromosomal Aberration Test}

Both direct and metabolic activation methods resulted in no significant difference from the control.

\subsection{Hemolysis Test}

In erythrocyte fragility test, electrolyzed acidic water provided higher hemolytic activity than distilled water.

\subsection{Single Dose Toxicity Test}

Mice dosed with electrolyzed acidic water showed no abnormality in body weight, general symptoms and 
macroscopic findings.

\subsection{Skin Toxicity Test by Repeated Immersion}

Rats immersed in electrolyzed acidic water demonstrated no adverse effect in skin, body weight, food intake, blood, biochemical, and pathological examinations.

\subsection{Antigenicity Test}

Guinea pigs sensitized to electrolyzed acidic water showed no anaphylactic symptoms.

\subsection{Cumulative Skin Irritation Test}

No change was observed in any rabbit skins treated with electrolyzed acidic water, demonstrating no skin irritancy.

\subsection{Primary Eye Mucosa Irritation Test}

After administration of eye drops of electrolyzed acidic water, no change was found in either non-eye washed, 2 -second or 4-second eye washed rabbit group.

\subsection{Oral Mucosa Irritation Test}

Electrolyzed acidic water was flowed into the oral cavity of hamsters at $1 \mathrm{ml} / \mathrm{min}$ for 10,20 or 30 minutes. The 10-minute or 20-minute flow caused no disorder. But the 30-minute flow resulted in mild histopathological degeneration of oral mucosa.

\subsection{Inhalation Toxicity Test}

The treated rats had no general symptoms and showed no change in body weight, food intake, blood, biochemical, and pathological examinations.

\subsection{Sensitization Test}

No sensitization was observed by hypodermic injection and induction of electrolyzed acidic water.

\subsection{Primary Skin Irritation Test on Rabbits}

The primary irritation index (P.I.I.) required in accordance with the Federal Register (1972) was 0.4 which falls within the non-irritating category.

\subsection{Colony Formation Inhibition Test with Cultured Cells}

In the direct exposure method, the $50 \%$ inhibitory concentration (IC50) by concentration-dependant inhibition of colony formation resulted in around $94.8 \%$. But in the culture medium mixture method, the analyte solution did not inhibit colony formation. These results showed that the direct exposure of cells to electrolyzed alkaline water obtained from the analyte caused slight cytotoxicity, but the exposure to alkaline water mixed with culture medium had no such effect.

\subsection{Marmot Skin Sensitization Test by Maximization Method}

Electrolyzed alkaline water was determined to have no skin sensitization potential.

\subsection{Acute Eye Mucosa Irritation Test}

After 1 hour from administration of eye drops containing $0.1 \mathrm{~mol} / \mathrm{L}$ sodium hydroxide solution, all samples showed conjunctival swelling (Grade 1) and increased ocular discharge (Grade 2). After 24 hours from administration, no conjunctival swelling was observed on any sample.

\subsection{Shelf Life of EOW}

When stored in an open container or direct sunlight, electrolyzed acidic water will rapidly lose available chlorine and should be used as soon as possible. But it will have a shelf life for several weeks when stored in shade in a sealed container [46].

\section{Conclusion}

EO water has great potential to compete with current methods. Need to optimize the process for individual applications. EOW treatment may be used as an effective method for reducing microbial contamination not only on food processing surfaces but also on non-food-contact surfaces such as ceramic tiles, floors, stainless steel, laboratory glassware, or medical or dental facilities and raw fruits or vegetables for pretreatment with EOW to reduce microbial load. Reduction of S. aureus, E. aerogenes and L. monocytogenes after treatment with EOW indicated that EOW can also prevent cross contamination from treatment solutions. As EOW is produced on-site and on demand for direct use, it can also reduce health hazards for workers by eliminating the need to handle concentrated chemicals. It may be useful as a food safety agent. EOW are useful in food manufacturing, depending on the food being produced. The use of EOW is an emerging technology and huge scope to further research and development to compete with current practices.

\section{REFERENCES}

[1] P. C. Chang, "HACCP Update in Fish Process in Taiwan," In: D. F. Hwang and T. Noguchi, Eds., Proceedings of International Scientific Symposium on Marine 
Toxins and Marine Food Safety, National Taiwan Ocean University, Keelung, 2003, pp. 137-141.

[2] Science and Education Impact, "Detecting Food Borne Enemies," 2001.

http://www.csrees.usda.gov/newsroom/impacts/01index/f oodborne.pdf

[3] S. Nakagawara, T. Goto and M. Nara, "Spectroscopic Characterization and the $\mathrm{pH}$ Dependence of Bactericidal Activity of the Aqueous Chlorine Solution," Analytical Sciences, Vol. 14, No. 4, 1998, pp. 691-698. doi:10.2116/analsci.14.691

[4] Y. C. Hung, "Personal Conversation about the Potential Benefits of Electrolyzed Water," 2005.

[5] C. Kim, Y. C. Hung and R. E. Brackett, "Roles of Oxidation-Reduction Potential in Electrolyzed Oxidizing and Chemically Modified Water for the Inactivation of Food-Related Pathogens," Journal of Food Protection, Vol. 63, No. 1, 2000, pp. 19-24.

[6] M. L. Bari, Y. Sabina and S. Isobe, "Effectiveness of Electrolyzed Acidic Water in Killing Escherichia coli O157:H7, Salmonella enteritidis, and Listeria monocytogenes on the Surfaces of Tomatoes," Journal of Food Protection, Vol. 66, No. 4, 2003, pp. 542-548.

[7] K. A. Fabrizio, R. R. Sharma and A. Demirci, "Comparison of Electrolyzed Oxidizing Water with Various Antimicrobial Interventions to Reduce Salmonella Species on Poultry," Poultry Science, Vol. 81, 2002, pp. 15981605.

[8] C. Kim, Y. C. Hung and R. E. Brachett, "Inactivation of Listeria Monocytogenes Biofilms by Electrolyzed Oxidizing Water," Journal of Food Processing and Preservation, Vol. 25, No. 2, 2001, pp. 91-100. doi:10.1111/j.1745-4549.2001.tb00446.x

[9] C. Kim, Y. C. Hung and R. E. Brackett, "Efficacy of Electrolyzed Oxidizing Water in Inactivating Salmonella on Alfalfa Seeds and Sprouts," Journal of Food Protection, Vol. 66, 2003, pp. 208-214.

[10] J. W. Buck, M. W. Iersel and R. D. Oetting, "In Vitro Fungicidal Activity of Acidic Electrolyzed Oxidizing Water," Plant Disease, Vol. 86, No. 3, 2002, pp. 278-281. doi:10.1094/PDIS.2002.86.3.278

[11] K. A. Fabrizio and C. N. Cutter, "Stability of Electrolyzed Oxidizing Water and Its Efficacy against Cell Suspensions of Salmonella typhimurium and Listeria monocytogenes," Journal of Food Protection, Vol. 66, No. 8, 2003, pp. 1379-1384.

[12] C. Morita, K. Sano and S. Morimatsu, "Disinfection Potential of Electrolyzed Solutions Containing Sodium Chloride at Low Concentrations," Journal of Virological Methods, Vol. 85, No. 1-2, 2000, pp. 163-174. doi:10.1016/S0166-0934(99)00165-2

[13] M. I. Al-Haq, Y. Seo and S. Oshita, "Fungicidal Effectiveness of Electrolyzed Oxidizing Water on Post Harvest Brown Rot of Peach," Horticultural Science, Vol. 36, No. 7, 2001, pp. 1310-1314.

[14] M. I. Al-Haq, Y. Seo and S. Oshita, "Disinfection Effects of Electrolyzed Oxidizing Water on Suppressing Fruit
Rot of Pear Caused by Botryosphaeria berengeriana," Food Research International, Vol. 35, No. 7, 2002, pp. 657-664. doi:10.1016/S0963-9969(01)00169-7

[15] H. Izumi, "Electrolyzed Water as a Disinfectant for Fresh-Cut Vegetables," Journal of Food Science, Vol. 64, No. 3, 1999, pp. 536-539. doi:10.1111/j.1365-2621.1999.tb15079.x

[16] K. S. Venkitanarayanan, G. O. Ezeike and Y. C. Hung, "Inactivation of Escherichia coli O157:H7 and Listera Moncytogenes on Plastic Kitchen Cutting Boards by Electrolyzed Oxidizing Water," Journal of Food Protection, Vol. 62, 1999, pp. 857-860.

[17] K. S. Venkitanarayanan, G. O. Ezeike and Y. C. Hung, "Efficacy of Electrolyzed Oxidizing Water for Inactivating Escherichia coli O157:H7, Salmonella enteritidis and Listeria monocytogenes," Applied and Environment Microbiology, Vol. 65, No. 9, 1999, pp. 4276-4279.

[18] C. M. Park, Y. C. Hung and R. E. Brackett, "Antimicrobial Effect of Electrolyzed Water for Inactivating Campylobacter jejuni during Poultry Washing," Inernational Journal of Food Microbiology, Vol. 72, No. 1-2, 2002, pp. $77-83$.

[19] S. Y. Hsu, "Effects of Flow Rate, Temperature and Salt Concentration on Chemical and Physical Properties of Electrolyzed Oxidizing Water," Journal of Food Engineering, Vol. 66, No. 2, 2005, pp. 171-176. doi:10.1016/j.jfoodeng.2004.03.003

[20] S. Shigeto, K. Matsumoto and H. Yaguchi, "Acidic Electrolyzed Water in the Disinfection of the Ocular Surface," Experimental Eye Research, Vol. 70, No. 1, 2000, pp. 1-6. doi:10.1006/exer.1999.0776

[21] S. M. Russell, "The Effect of Electrolyzed Oxidative Water Applied Using Electrostatic Spraying on Pathogenic and Indicator Bacteria on the Surface of Eggs," Poultry Science, Vol. 82, No. 1, 2003, pp. 158-162.

[22] Y. Sakurai, M. Nakatsu and Y. Sato, "Endoscope Contamination from HBV- and HCV-Positive Patients and Evaluation of a Cleaning/Disinfecting Method Using Strongly Acidic Electrolyzed Water," Digestive Endoscopy, Vol. 15, No. 1, 2003, pp. 19-24. doi:10.1046/j.1443-1661.2003.00212.x

[23] N. Tanaka, T. Fujisawa and T. Daimon, "The Effect of Electrolyzed Strong Acid Aqueous Solution on Hemodialysis Equipment," Artificial Organs, Vol. 23, No. 12, 1999, pp. 1055-1062. doi:10.1046/j.1525-1594.1999.06224.x

[24] S. P. Walker, A. Demirci and R. E. Graves, "CIP Cleaning of a Pipeline Milking System Using Electrolyzed Oxidizing Water," International Journal of Dairy Technology, Vol. 58, 2005, pp. 65-73. doi:10.1111/j.1471-0307.2005.00190.x

[25] H. Kiura, K. Sano and S. Morimatsu, "Bactericidal Activity of Electrolyzed Acid Water from Solution Containing Sodium Chloride at Low Concentration, in Comparison with That at High Concentration," International Journal of Food Microbiololgy Methods, Vol. 49, 2002, pp. 285-293. 
[26] B. Ayebah and Y. C. Hung, "Electrolyzed Water and Its Corrosiveness on Various Surface Materials Commonly Found in Food Processing Facilities," Journal of Food Process Engineering, Vol. 28, No. 3, 2005, pp. 247-264. doi:10.1111/j.1745-4530.2005.00424.X

[27] S. Koseki, K. Yoshida and Y. Kamitani, "Effect of Mild Heat Pre-Treatment with Alkaline Electrolyzed Water on the Efficacy of Acidic Electrolyzed Water against Escherichia coli O157:H7 and Salmonella on Lettuce," Food Microbiol, Vol. 21, No. 5, 2004, pp. 559-566. doi:10.1016/j.fm.2003.11.004

[28] C. Kim, Y. C. Hung and R. E. Brachett, "Roles of Oxidation-Reduction Potential in Electrolyzed Oxidizing and Chemically Modified Water for Inactivation of FoodRelated Pathogens," Journal of Food Protection, Vol. 63, 2000, pp. 19-24.

[29] H. Park, Y. C. Hung and D. Chung, "Effects of Chlorine and $\mathrm{pH}$ on Efficacy of Electrolyzed Water for Inactivating Escherichia coli O157:H7 and Listeria monocytogenes," International Journal of Food Microbiololgy, Vol. 91, No. 1, 2004, pp. 13-18. doi:10.1016/S0168-1605(03)00334-9

[30] S. V. Len, Y. C. Hung and M. Erickson, "Ultraviolet Spectrophotometric Characterization and Bactericidal Properties of Electrolyzed Oxidizing Water as Influenced by Amperage and pH," Journal of Food Protection, Vol. 63, No. 11, 2000, pp. 1534-1537.

[31] M. Sakashita, A. Iwasawa and Y. Nakamura, "Antimicrobial Effects and Efficacy on Habitually Hand-Washing of Strong Acidic Electrolyzed Water-A Comparative Study of Alcoholic Antiseptics and Soap and Tap Water," Journal of Japanese Association of Infectious Diseases, Vol. 76, No. 5, 2002, pp. 373-377.

[32] H. Park, Y. C. Hung and C. Kim, "Effectiveness of Electrolyzed Water as a Sanitizer for Treating Different Surfaces," Journal of Food Protection, Vol. 65, No. 8, 2002, pp. 1276-1280.

[33] Y. R. Huang, H. S. Hsieh and S. Y. Lin, "Application of Electrolyzed Oxidizing Water on the Reduction of Bacterial Contamination for Seafood," Food Control, Vol. 17, 2006, pp. 987-993. doi:10.1016/j.foodcont.2005.07.003

[34] L. B. Liao, W. M. Chen and X. M. Xiao, "The Generation and Inactivation Mechanism of Oxidation-Reduction Potential of Electrolyzed Oxidizing Water," Journal of Food Engineering, Vol. 78, No. 4, 2007, pp. 1326-1332. doi:10.1016/i.jfoodeng.2006.01.004

[35] S. V. Len, Y. C. Hung and D. Chung, "Effects of Storage Conditions and $\mathrm{pH}$ on Chlorine Loss on Electrolyzed Oxidizing (EO) Water," Journal of Agricultural Food Chemistry, Vol. 50, 2002, pp. 209-212.

\section{doi:10.1021/jf010822v}

[36] S. H. Hsu and H. Y. Kao, "Effect of Storage Conditions on Chemical and Physical Properties of Electrolyzed Oxidizing Water," Journal of Food Engineering, Vol. 65, 2004, pp. 465-471. doi:10.1016/j.jfoodeng.2004.02.009

[37] T. Oomori, T. Oka, T. Inuta and Y. Arata, "The Efficiency of Disinfection of Acidic Electrolyzed Water in the Presence of Organic Materials," Analytical Science, Vol. 16, No. 4, 2000, pp. 365-369. doi:10.2116/analsci.16.365

[38] N. G. Marriott and R. B. Gravani, "Principles of Food Sanitation," 5th Edition, Springer, New York, 2006.

[39] S. L. Wilkinson, "Eating Safely in a Dirty World," Chemical \& Engineering News, 10 November 1997, pp. 2433. doi:10.1021/cen-v075n045.p024

[40] N. Achiwa, N. G. Marriott and R. B. Gravani, "Efficacy of Electrolyzed Acidic Water for Disinfection and Quality Maintenance of Fresh-Cut Cabbage," Food Preservation Science, Vol. 29, No. 6, 2003, pp. 341-346. doi:10.5891/jafps.29.341

[41] S. Koseki, K. Yoshida and S. Isobe, "Efficacy of Acidic Electrolyzed Water for Microbial Decontamination of Cucumbers and Strawberries," Journal of Food Protection, Vol. 67, No. 6, 2004, pp. 1247-1251.

[42] C. M. Park, Y. C. Hung and M. P. Doyle, "Pathogen Reduction and Quality of Lettuce Treated with Electrolyzed Oxidizing and Acidified Chlorinated Water," Journal of Food Science, Vol. 66, No. 9, 2001, pp. 1368-1372. doi:10.1111/j.1365-2621.2001.tb15216.x

[43] N. P. Ozer and A. Demirci, "Electrolyzed Oxidizing Water Treatment for Decontamination of Raw Salmon Inoculated with Escherichia coli O157:H7 and Listeria monocytogenes Scott A and Response Surface Modeling," Journal of Food Engineering, Vol. 72, No. 3, 2006, pp. 234-241. doi:10.1016/j.jfoodeng.2004.11.038

[44] C. Liu and Y. C. Su, "Efficiency of Electrolyzed Oxidizing Water on Reducing Listeria Monocytogenes Contamination on Seafood Processing Gloves," International Journal of Food Microbiololgy, Vol. 110, 2006, pp. 149154. doi:10.1016/j.ijfoodmicro.2006.02.004

[45] C. Liu, J. Duan, Y. C. Su, "Effects of Electrolyzed Oxidizing Water on Reducing Listeria Monocytogenes Contamination on Seafood Processing Surfaces," International Journal of Food Microbiololgy, Vol. 106, No. 3, 2006, pp. 248-253. doi:10.1016/j.ijfoodmicro.2005.06.020

[46] "Electrolyzed Water: Information Document," Hoshizaki Europe, B. V. Lemelerbergweg 511101 AM, Amsterdam. 